\title{
EFFECTS OF IMPLEMENTING THE BONUS SYSTEM MODERNIZATION IN A SMALL COMPANY
}

\author{
Michał BARTNICKI \\ Silesian University of Technology; Michal.Bartnicki@polsl.pl, ORCID: 0000-0002-0998-4494
}

Purpose: The purpose of the study was to assess the theoretical model, representing original approach of bonus system created by the author, after several years of its functioning in the real environment. The model aims at supporting identification of salaries levels of sellers employed in a marketing company.

Design/methodology/approach: In 2015, a proprietary modification of the new bonus system in a small company was developed, which was aimed at directing the efforts of sellers at building added value in the company. The developed modification was implemented as a practical solution. This study is an attempt to confront the adopted theoretical assumptions presented in the article "Modernisation of the bonus system in a small company," which was published in the Scientific Notebooks of the Silesian University of Technology (Zeszyty Naukowe Politechniki Śląskiej), with the actual results of the bonus system in the indicated company.

Findings: The study presents the basic parameters illustrating changes in the company after introduction of the new bonus system. Moreover, it shows the impact of the introduced variations on the salary of individual sellers.

Originality/value: The originality aspect of the study was the practical verification of the original author's method for settling remuneration among sales employees.

Keywords: bonus system, added value, profit.

\section{Introduction}

There was a remuneration system in a sales company, which was based on commission remuneration (Prętczyńska, 2009; http://kadry.infor.pl/... The system's operation in general assumptions was to pay a seller a $5 \%$ commission for a contract signed during the first 12 months of the agreement and 3\% commission for the next 12 months. In case of a longer duration of the seller's contract, no commission was paid. 
Such a system favoured the so-called "Leaky bucket" (Acocella, 2002; http://www.marketingowa-moc.pl/...) because despite signing new contracts, the seller was not motivated to maintain commitments longer than 24 months. Such a system also encouraged the resumption of contracts under slightly modified conditions, which again triggered the payment of commission for sales. At the same time, this did not result in an increase in profits for the company and was a form of generating undue revenues for sellers (Król, Ludwiczyński, 2007, Prętczyńska, 2009; http://kadry.infor.pl/...; Ustawa z dnia 26 czerwca 1974 r...). In 2015, a new bonus system was developed, which was implemented on 01.01.2016 and covered all sales employees whose remuneration was based on the commission system.

\section{Purpose of the study}

Considering the problem outlined above, as the purpose of the study was to check and compare the theoretical assumptions adopted in the study in 2015 with the actual system functioning from $01 / 01 / 2016$ to $31 / 12 / 2018$, i.e., during full three calendar years. In particular, it was verified to what extent the assumptions from 2015 worked in reality and whether the goals set at the time were met:

1) Fixed and fair commission for salespeople.

2) The motivation of sellers to increase the revenues and profits of the company.

3) Acquiring new customers while maintaining the motivation to carefully serve the existing customers.

4) Introduction of a mechanism which, to the greatest extent possible, prevents the occurrence of the so-called "leaky bucket" effect and resumption of contracts with contractors which would be treated as new contracts (http://wyborcza.biz/...).

\section{Assumptions for the system and the operational rules of the bonus system}

The following initial assumptions were adopted as the basis for the construction of the remuneration system in 2015:

1. Data for the bonus system should be loaded from the CRM system operating in the company.

2. All profits are calculated as the difference between the value of the VAT invoice item issued to the customer and the direct costs assigned to this item.

3. The commission remuneration should be payable on all profits generated by an employee. 
4. The highest commission share is obtained by a seller from new profits appearing on accounts of individual clients and their product groups.

The algorithm for determining bonus remuneration was implemented in the following steps:

- Loading data from the CRM system to the details of the 'invoice item' data.

- Determination of profit on the invoice item designated as:

$$
\text { profit }=\frac{\text { place }- \text { value of the VAT invoice }- \text { costs assigned to the item }}{\text { the number of employees assigned to the item }}
$$

Profit is calculated for each customer and each type of product offered.

Three types (T) of products were named, respectively: P1, P2, P3.

- All profits in a month for a pair ( $\mathrm{K}$ - Customer; $\mathrm{T}$ - type) are added together.

- Four time periods are established in which historical data on sales profits for the KT pair are analysed, named as groups from 0 to III covering respectively the following periods:

- Group 0 - current month (the first accounting month from which profits commission is paid).

- Group I - past months from 2 to 12 before the current one.

- Group II - past months from 13 to 24 before the current one.

- Group III - past months from 25 to 36 before the current one.

- The medians of the KT pair's profits are determined in the periods:

- Between the 36th and 25th month included before the accounting month the median of group III.

- Between the 13th and 24th month included before the accounting month the median of group II.

- Between the 2nd and 12th month included before the accounting month the median of group I.

- The sum of monthly profits for a KT pair is classified into one of four groups:

- To group III - classified part of profit equal to the median of group III.

- To group II - classified part of profit equal to the median of group II reduced by the value assigned to group III.

- To group I - classified part of profit equal to the median of group I reduced by the value assigned to groups II and III.

- To group 0 - the remaining part of the profit, the so-called "New profit."

- The developed model introduces the possibility of adding adjustment of base rates depending on the source of customer acquisition. Base rates can be adjusted for groups 0 , I and II. The lowest class (III) is not adjusted. The following correction factors have been initially proposed:

- $0.1 \%$ - for profits from customers acquired from the company's database.

- $0.2 \%$ - for profits from customers who contacted the company themselves.

- $0.3 \%$ - for profits from customers acquired from other employees of the company. 
There was no rate correction mechanism in the real system.

- The commission remuneration for individual items is calculated as the product of the class value and its adjusted commission factor.

- Individual partial components are added, thus obtaining the total commission fee in a month.

\section{The main effects of the introduction of a new bonus system}

As part of the study, employee sales data were analysed over the years 2011-2018. All data were obtained from the CRM (Customer Relationship Management) system of the analysed company. The eight years of the research scope included five years of operation based on the original bonus system, i.e. 2011-2015, and three years of operation based on the modified bonus system, i.e., the years 2016-2018. Table 1 presents the data of individual sellers (designation S1-S4) regarding the profits obtained from contracts signed with contractors, the value of commissions achieved, and the number of contracts from which the profit was obtained and, consequently, commissions were paid. The data were synthesised to calendar years, and all groups of products sold were aggregated.

Table 1.

The results achieved in each year

\begin{tabular}{|c|c|c|c|c|c|c|c|c|c|c|c|c|}
\hline & \multicolumn{3}{|c|}{ S1 } & \multicolumn{3}{|c|}{ S2 } & \multicolumn{3}{|c|}{ S3 } & \multicolumn{3}{|c|}{ S4 } \\
\hline Year & Number & Commission & Profit & Number & Commission & Profit & Number & Commission & Profit & Number & Commission & Profit \\
\hline 2018 & 2,143 & 995,506 & $2,686,576$ & 2,735 & $\begin{array}{l}52,568 \\
\end{array}$ & $2,069,111$ & 977 & $\begin{array}{l}19,599 \\
\end{array}$ & $\begin{array}{l}542,024 \\
\end{array}$ & $1,1,353$ & 30,203 & $1,012,819$ \\
\hline 2017 & 1,805 & 85,801 & $2,608,219$ & 2,383 & 43,961 & $1,643,333$ & 782 & 15,301 & 416,965 & 972 & 28,410 & 686,010 \\
\hline 2016 & 1,520 & 73,786 & $1,834,970$ & 1,948 & 36,358 & $1,325,430$ & 682 & 13,193 & 377,727 & 909 & 20,477 & 587,405 \\
\hline 2015 & 1,228 & 57,412 & $1,299,392$ & 1,436 & 37,473 & 990,677 & 431 & 11,092 & 273,978 & 567 & 19,481 & 421,436 \\
\hline 2014 & 1,263 & 60,416 & $1,459,993$ & 1,287 & 22,189 & 833,253 & 514 & 8,741 & 218,839 & 681 & 12,426 & 307,003 \\
\hline 2013 & 971 & 47,268 & $1,128,917$ & 1,418 & 18,648 & 874,710 & 409 & 4,799 & 149,110 & 481 & 6,637 & 164,472 \\
\hline 2012 & 886 & 34,313 & 858,454 & 1,571 & 20,506 & $1,020,316$ & 376 & 6,919 & 176,924 & 419 & 4,575 & 126,627 \\
\hline 2011 & 777 & 20,855 & 601,136 & 1,301 & 13,957 & 813,381 & 278 & 5,219 & 133,108 & 355 & 6,324 & 148,278 \\
\hline
\end{tabular}

Subsequently, the data was cumulated to the total level achieved by sellers (Table 2).

Table 2.

Basic parameters achieved in individual years

\begin{tabular}{|c|c|c|c|c|c|c|}
\hline Year & $\begin{array}{c}\text { Number of } \\
\text { contracts }\end{array}$ & Commission paid & Profit & $\begin{array}{c}\text { The average } \\
\text { \% of } \\
\text { commission } \\
\text { paid }\end{array}$ & $\begin{array}{c}\text { PLN } \\
\text { commission } \\
\text { per contract }\end{array}$ & $\begin{array}{c}\text { PLN profit } \\
\text { per contract }\end{array}$ \\
\hline 2018 & 7,208 & 203,876 & $6,310,530$ & $3.23 \%$ & 28.3 & 875 \\
\hline 2017 & 5,942 & 173,473 & $5,354,527$ & $3.24 \%$ & 29.2 & 901 \\
\hline 2016 & 5,059 & 143,814 & $4,125,532$ & $3.49 \%$ & 28.4 & 815 \\
\hline 2015 & 3,662 & 125,458 & $2,985,483$ & $4.20 \%$ & 34.3 & 815 \\
\hline 2014 & 3,745 & 99,240 & $2,819,089$ & $3.52 \%$ & 26.5 & 753 \\
\hline 2013 & 3,279 & 77,352 & $2,317,209$ & $3.34 \%$ & 23.6 & 707 \\
\hline 2012 & 3,252 & 66,314 & $2,182,320$ & $3.04 \%$ & 20.4 & 671 \\
\hline 2011 & 2,711 & 46,356 & $1,695,902$ & $2.73 \%$ & 17.1 & 626 \\
\hline
\end{tabular}


The presented data were compared with the data on which the study was conducted in 2016 (designated in bold), and it was found that they are consistent. This consistency empowered the further analysis.

In the research in 2016 it was noticed that there was a sudden increase in the average commission paid, which in 2015 reached an average of $4.20 \%$. Such a high share of the commission was due to the "leaky bucket" effect of the original bonus system. The modified system was supposed to stop this effect. According to the simulations of that time, the parameters of the new bonus system were selected so that the average percentage of commission paid was set at the level of about 3.2\%. As can be seen in Table 1, in 2016-2018, the real rate of commission paid was obtained at the level of $3.23 \%-3.49 \%$. The average percentage of commission paid in 2016 (3.49\%) was slightly higher than theoretically assumed, as sales to new customers increased above the level expected in the original study. The modification of the bonus system was to additionally promote sales to new customers. Table 3 summarizes the dynamics of changes in individual parameters year to year ( $y / y)$.

Table 3.

Changes of individual parameters $y / y$

\begin{tabular}{|c|c|c|c|}
\hline Years & $\begin{array}{c}\text { Change in the number of } \\
\text { contracts y / y in \% }\end{array}$ & $\begin{array}{c}\text { Change in commission value } \\
\mathbf{y} / \mathbf{y} \text { in } \%\end{array}$ & $\begin{array}{c}\text { Change in profit y / y in } \\
\text { \% }\end{array}$ \\
\hline 2018 & $21.3 \%$ & $17.5 \%$ & $17.9 \%$ \\
\hline 2017 & $17.5 \%$ & $20.6 \%$ & $29.8 \%$ \\
\hline 2016 & $38.1 \%$ & $14.6 \%$ & $38.2 \%$ \\
\hline 2015 & $-2.2 \%$ & $20.9 \%$ & $5.9 \%$ \\
\hline 2014 & $14.2 \%$ & $34.2 \%$ & $21.7 \%$ \\
\hline 2013 & $0.8 \%$ & $16.6 \%$ & $6.2 \%$ \\
\hline 2012 & $20.0 \%$ & $43.1 \%$ & $28.7 \%$ \\
\hline 2011 & \multicolumn{3}{|c|}{ Base for the year 2012} \\
\hline
\end{tabular}

From the analysis of Table 3 data, the following observations can be made.

1. The bonus system operating until 2015:

a) It rewarded salespeople well, ensuring high dynamics of paid commissions y / y.

b) At the same time, it did not motivate them to attract new customers. It became particularly noticeable in 2015 when with a nominal increase in commissions and their growth y / y dynamics at the level of $20.9 \%$, there was a decrease in contracts from which commissions were paid by $-2.2 \%$. This means that sellers achieved a certain level of satisfaction with the achieved remuneration, focusing at the same time on servicing existing customers and signing subsequent contracts so that they would be treated as new contracts, which resulted in remuneration with increased commission.

c) Slower growth of the company's profit dynamics. These dynamics in 2015 was $5.9 \%$ $\mathrm{y} / \mathrm{y}$ with the dynamics of commission paid at the already indicated level of $20.9 \%$ $\mathrm{y} / \mathrm{y}$. This phenomenon had analogous reasons as the one cited in the previous item. 
2. The bonus system introduced at the beginning of 2016 :

a) It resulted in significant increases in the number of clients and contracts from which the commission was paid. A spectacular increase was recorded in 2016, in which year the dynamics of the number of clients increased by $38.1 \% \mathrm{y} / \mathrm{y}$. This means that there were major undeveloped reserves on the market, and the existing system did not motivate sellers to acquire them. The prospect of an increase in the remuneration for acquiring new customers and the possibility of reducing the commission remuneration for servicing existing customers motivated sellers to take action to attract new customers.

b) The increased number of contracts was followed by increased profits of the company, whose dynamics in 2016 amounted to $38.2 \% \mathrm{y} / \mathrm{y}$.

c) In 2017 and 2018, the high dynamics of acquiring new customers and achieved profits was maintained (Table 3). They were not, obviously, as high as in 2016 when a significant part of the market was developed.

d) The new bonus system maintained satisfactory dynamics of increase in paid commissions, which in the years of new bonus system operation were formed in the range of $14.6 \%-20.6 \% \mathrm{y} / \mathrm{y}$ giving total dynamics in this period at the level of $63 \%$.

\section{Impact of changing the bonus system on the salaries of individual sellers}

The next step of the study was the preliminary analysis of how a change in the bonus system influenced the commission paid to individual employees. Table 4 presents the commission remuneration of individual employees over the years 2011-2018.

Table 4.

Commission remuneration in years

\begin{tabular}{|c|c|c|c|c|c|}
\hline Years & S1 & S2 & S3 & S4 & Sum \\
\hline 2018 & $95,506.0$ & $52,568.0$ & $19,599.0$ & $36,203.0$ & $203,876.0$ \\
\hline 2017 & $85,801.0$ & $43,961.0$ & $15,301.0$ & $28,410.0$ & $173,473.0$ \\
\hline 2016 & $73,786.0$ & $36,358.0$ & $13,193.0$ & $20,477.0$ & $143,814.0$ \\
\hline 2015 & $57,411.8$ & $37,473.0$ & $11,092.3$ & $19,481.3$ & $125,458.4$ \\
\hline 2014 & $60,416.5$ & $22,188.7$ & $8,740.8$ & $12,426.0$ & $103,772.0$ \\
\hline 2013 & $47,267.6$ & $18,648.1$ & $4,798.7$ & $6,637.4$ & $77,351.8$ \\
\hline 2012 & $34,313.1$ & $20,506.2$ & $6,919.3$ & $4,575.3$ & $66,313.9$ \\
\hline 2011 & $20,854.8$ & $13,957.4$ & $5,219.3$ & $6,324.2$ & $46,355.7$ \\
\hline
\end{tabular}

As can be seen in the table, the commission remuneration of individual employees is continuously increasing. Despite the change in the bonus system, which increased the profitability of the company and contributed to the increase in the number of customer service, the high dynamics of the salary increase of individual employees was maintained. The salary 
remuneration dynamics since the introduction of the new bonus system, i.e., since the end of 2015 , is presented in Table 5 .

Table 5.

Average monthly remuneration and the dynamics of changes in payment after the introduction of the new bonus system

\begin{tabular}{|c|c|c|c|c|c|}
\hline Years & S1 & S2 & S3 & S4 & Sum \\
\hline 2018 & $7,958.8$ & $4,380.7$ & $1,633.3$ & $3,016.9$ & $16,989.7$ \\
\hline 2015 & $4,784.3$ & $3,122.8$ & 924.4 & $1,623.4$ & $10,454.9$ \\
\hline Dynamics 2015 -2018 & $66 \%$ & $40 \%$ & $77 \%$ & $86 \%$ & $63 \%$ \\
\hline
\end{tabular}

Detailed analysis of the impact of the introduction of a new bonus system on individual employees will be the subject of further research.

\section{Conclusions}

It was confirmed in practice that the developed bonus system, which was described in the author's work under the title "Modernization of the bonus system in a small company", published in the scientific journal of the Silesian Technical University, meets the assumptions expected and predicted at that time.

Figure 1 presents the quarterly profit chart for 2011-2018.

It can be observed that the dynamics of profit increase, starting from the first quarter of 2016, is increasing. In particular, the system rewards new profits obtained from individual clients and new clients without reducing the overall commission remuneration.

At the same time, the system prevents the possibility of resuming, as new, the same products within one customer. Additionally, the system encourages the representative to maintain relationships with customers acquired earlier, because the commission, although lower than in the case of a new contract, is continuously maintained.

An in-depth analysis of the impact of changing the bonus system on individual employees seems to be an interesting research material. This material will be further analysed, and its results will be presented in subsequent publications. 


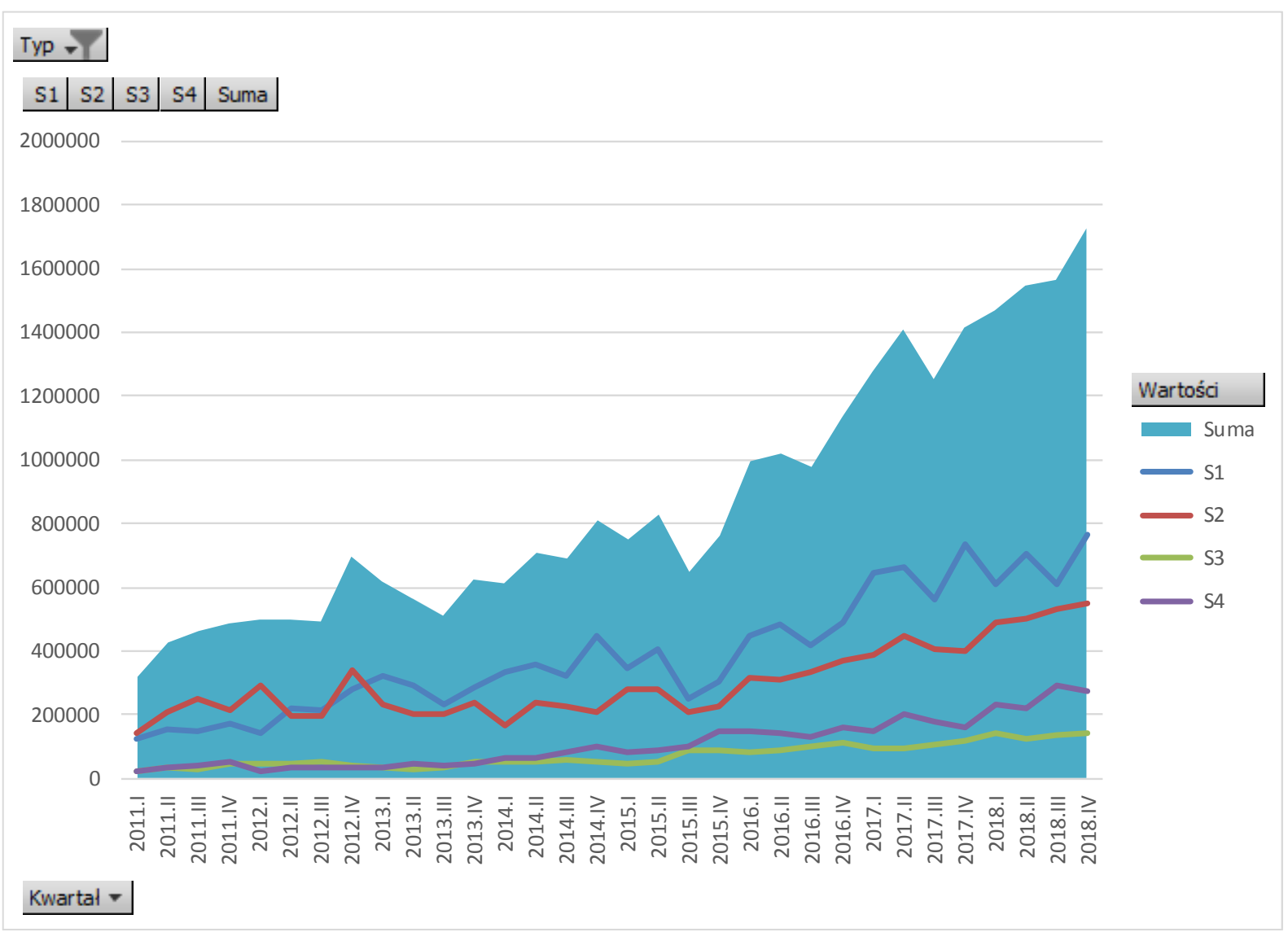

Figure 1. Quarterly dynamics of profit increase over 2011-2008.

\section{References}

1. Acocella, N. (2002). Zasady polityki gospodarczej. Warszawa: PWN.

2. Jankowski, M. (2011). Pułapki small biznesu. 133 mity, które niszcza Twoja firmę. Gliwice: Onepress.

3. Król, H., Ludwiczyński, A. (2007). Zarządzanie zasobami ludzkimi. PWN.

4. Prętczyńska, A. (2009). Akordowy system wynagradzania. Monitor Prawa Pracy, 4.

5. Stratten, S. (2012). BezMarketing. Przestań kusić klientów, zacznij z nimi rozmawiać! (UnMarketing: Stop Marketing. Start Engaging). Gliwice: Onepress.

6. http://kadry.infor.pl/kadry/wynagrodzenia/rozliczanie_wynagrodzen/662135,Kiedy-wartowprowadzic-w-firmie-prowizyjny-system-wynagradzania.html.

7. http://www.marketingowa-moc.pl/efekt-dziurawego-wiadra/.

8. http://wyborcza.biz/biznes/2,114423,,Rolowanie_kontraktu,,156343712,11603.html?disab leRedirects $=$ true, 19.02.2016.

9. Ustawa z dnia 26 czerwca 1974 r., Kodeks pracy (Dz.U. z 1998 r. Nr 21, poz. 94 z późn. Zmianami. 